\title{
Белешов А. А.
}

\section{ОПРЕДЕЛЕНИЕ КОНСТИТУЦИОНАЛИЗМА В РОССИЙСКОЙ ЮРИДИЧЕСКОЙ ПАРАДИГМЕ}

\author{
Beleshov A. A. \\ DEFINITION OF CONSTITUTIONALISM \\ IN THE RUSSIAN LEGAL PARADIGM
}

\begin{abstract}
В статье рассматриваются различные подходы к определению понятия конституционализма в существующей на территории Российской Федерации юридической парадигме. В Российской юридической парадигме понятие конституционализма до сих пор строго не определено. Сложность определения данного понятия заключается не только в его многоаспектности, но и в том, что в течение долгого промежутка времени конституционализму не уделялось должного внимания. В настоящей статье раскрывается многообразие подходов при определении понятия конституционализма в Российской юридической науке. Так как в Российской юридической науке отсутствует единый подход к определению понятия «Конституционализм», в статье рассматриваются различные существующие подходы к его формулировке не только с философско-правовой стороны, но и с возможности применения рассматриваемых подходов на практике. Проведенный анализ подходов позволяет прийти к выводу о наличии расхождений между существующими подходами и Российской действительностью.
\end{abstract}

Ключевые слова: конституционализм, конституция, юридическая парадигма, развитие конституционализма.

The article examines various approaches to defining the concept of constitutionalism in the legal paradigm existing on the territory of the Russian Federation. In the Russian legal paradigm, the concept of constitutionalism is still not strictly defined. The complexity of the definition of this concept lies not only in its multidimensionality, but also in the fact that for a long period of time, constitutionalism was not given due attention. This article reveals a variety of approaches in defining the concept of constitutionalism in the Russian legal science. Since in the Russian legal science there is no unified approach to the definition of the concept of "Constitutionalism", the article examines various existing approaches to its formulation not only from the philosophical and legal side, but also from the possibility of applying the considered approaches in practice. The analysis of the approaches allows us to conclude that there are discrepancies between the existing approaches and the Russian reality.

Keywords: constitutionalism, constitution, legal paradigm, development of constitutionalism.

В Российской юридической литературе неоднократно производились попытки по приведению различных подходов к конституционализму к единой классификации [1]. Конституционализм в Российской юридической науке длительное время не был выделен как отдельная смысловая категория и долгое время понятие «Конституционализм» использовалось в качестве равнозначного понятия таким структурам как: «Конституционное право», «Конституция», «Конституционный строй» 2 , с.53].
С конца 2-го века на территории России возросло количество обсуждений о сущности конституционализма, а также, какое влияние данное явление может оказать на Российскую политическую и правовую системы. Осмысление особенностей и правовых основ Российского конституционализма как отдельной смысловой категории, прежде всего, обусловлено прошедшими политико-правовыми преобразованиями.

В Российской юридической парадигме понятие конституционализма до сих 
пор строго не определено. Сложность определения данного понятия заключается не только в его многоаспектности, но и в том, что в течение долгого промежутка времени конституционализму не уделялось должного внимания. Существующее многообразие подходов при определении понятия конституционализма в Российской юридической науке позволит приблизится к пониманию не только существующих проблем, но и наметить будущие пути его развития.

И.М. Степанов в своей работе начала 90-х годов указывал, что конституционализм по своей сути является «системой представлений об общедемократических, общецивилизационных политикоправовых ценностях государственно организованного общества» [3, с. 30]. Именно И.М. Степанов в период перестройки указывал на отсутствие необходимости в противопоставлении двух типов конституционализма. Он считал, что в основах любой системы, должны лежать общечеловеческие ценности. При этом он разграничивал конституционализм в широком и узком смысле понимания данного термина. В узком смысле под конституционализмом он понимал систему знаний об основополагающих принципах демократии: их формах, составе, методах и реализации. А в широком смысле И.М. Степанов характеризовал конституционализм как систему, в которую входит не только теория конституции, но и практика и история развития отдельно взятой страны, группы стран или мирового сообщества в целом [4, с. 3].

С.А. Авакьян высказывает мнение о том, что само понятие «общецивилизационных» и «общедемократических» ценностей является очень относительным, которое нельзя рассматривать как аксиоматическую заданность, а скорее следует рассматривать как набор ценностей, который относится к каждому конкретному государству [5, с. 229]. При этом он связывает конституционализм со следующими ключевыми моментами: конституционные идеи совместно с наличием соответствующего нормативно-правового фундамента, политический режим, соотносящийся с конституцией, а так же наличие системы защиты конституции и конституционного строя [6, с. 229-232].

При этом Ромашов Р.А. считает, что конституционализм является политическо-правовым явлением, включающее в себя не только действующее законодательство и сформированную практику, но и идейную доктрину, а по своей сути, по мнению Ромашова Р.А. феномен консти- туционализма является причиной ограничения действующей государственной власти основным законом - конституцией $[7$, c. 68$]$.

Таким образом, само понятие конституционализма можно соотнести с правовой идеологией в соответствии с которой существуют механизмы, направленные на ограничение возможностей злоупотреблением власти и сохранения прав человека как основного элемента всей структуры.

Так, по мнению Баева В.Г. существенным признаком конституционализма является наличие реальных инструментов ограничения государственной власти, совместно с формальным соблюдением конституции [8, с. 47].

Данного взгляда на конституционализм придерживается целый ряд Российских ученых-правоведов. Так например, Б.А. Старшун под основополагающей чертой конституционализма понимает гарантию прав и свобод человека, а так же систему разделения властей, которая способствует ограничению власти над человеком со стороны государства [9, с. 43]. В.Г. Графский считает, что ограничение деятельности власти является основной функцией и задачей конституционализма [10, с. 12].

В.Т. Кабышев формулирует понятие конституционализму как философию конституционного мировоззрения, в купе с закреплением в Основном законе системы правовых ценностей, действующей системы верховенства конституции, ее приоритетности и реальности, а так же осуществление государственной власти в рамках, заданных конституцией $[11$, с. 63].

Конституционализм, как политикоправовой режим был рассмотрен А.Н. Кокотовым и Л.В. Сониной. С их точки зрения, конституционализм является политико-правовым режимом, заключающийся в установлении начал конституционности в постиндустриальном обществе, преследующий цели его равновесного развития, путем воплощения в правосознании идеи верховенства прав и свобод человека и гражданина, демократии, гласности и разделения властей, а также путем выделения социальных групп, отстаивающих эти идеи [12, с. 131].

Не следует забывать о такой стороне теории конституционализма, как ее практическое применение. Выделяется несколько видов конституционализма, складывающиеся на практике в большинстве государства.

В качестве одной из форм конституци- 
онализма А.А. Арутюнян выделяет «фонмальный» конституционализм. Его особенностями является непосредственное наличие основного закона - конституции, определяющей полномочия и сам принцип разделения властей, а также закрепляющей и гарантирующей основные права граждан [13, с. 85].

В.Е. Чиркин, ввел понятие «ущербного конституционализма». В соответствии с его позицией конституция по своему содержанию должна быть демократической по своему содержанию, толкованию и применению, а также социально направленной. При отсутствие какого либо элемента конституционализм, по мнению B.Е. Чиркина, приобретает ущербный характер [14, с. 82].

И.А. Кравец рассматривает конституционализм не только как нормативноправовую систему, но и указывает на то, что конституционализм как явление опи- рается на сформированные ценности, как неотъемлемую часть правовой культуры [15, с. 187-190].

Таким образом, в Российской юридической науке имеет место широкое разнообразие подходов к определению феномена конституционализма. Данное разнообразие обусловлено тем, что российская юридическая парадигма насыщена собственными, индивидуальными особенностями, придающими ей неповторимую неоднородную окраску. Но так или иначе современные подходы к определению конституционализма сводятся к тому, что это многокомпонентная философско-правовая система, находящая прямое свое отражение в конституции государства, закрепляющая и гарантирующая соблюдение общечеловеческих прав и свобод, а также ограничивающая власть над человеком со стороны государства.

\section{Литература}

1. Бочкарев С.В. Теоретико-правовое определение функционального конституционализма в отечественной юриспруденции // Правовая инициатива. -2014. - №2 [Электронный ресурc]. - URL: http://xn--b1aiui.xn--p1ai/ru/2014/2/7 (дата обращения: 22.12.2020)

2. Кабышев В.Т. Российский конституционализм: тенденции и перспективы развития // Российская юридическая доктрина в XXI веке: проблемы и пути их решения: Научно-практическая конференция (3-4 октября 2001г.) / под ред. А.И. Демидова. - Саратов: СГАП, 2001.

3. Степанов И.М. Грани Российского конституционализма (XX век) // Конституционный строй России. - Вып.І. - М., 1992.

4. Степанов И.М. Уроки и парадоксы российского конституционализма. Очеркэссе. - M.,1996.

5. Авакьян С.А. Конституция России: природа, эволюция, современность. 2-е изд. - М.,2000.

6. Авакьян С.А. Конституция России: природа, эволюция, современность. 2-е изд. - М.,2000.

7. Ромашов Р.А. Конституционное государство (история, современность, перспективы развития). - Красноярск: Краснояр. гос. ун-т, 1997.

8. Баев В.Г. Конституционализм как понятие и научная проблема // Ленинградский юридический журнал. - 2008. - №3(13). - С. 44 - 62.

9. Старшун Б.А. Конституционализм: идеал, реальность и возможные перспективы // Сравнительное конституционное обозрение. - 2011. - №5. - С. 43

10. Графский В.Г. Конституционализм как предмет изучения // Право. Журнал Высшей школы экономики. - 2009. - №3. - С. 3 - 13.

11. Кабышев В.Т. Российский конституционализм на рубеже тысячелетий // Известия вузов. Правоведение. - 2001. - №4.

12. Кокотов А.Н., Сонина Л.В. Конституционализм как политико-правовой режим // Российский юридический журнал. - 2001. - №1. - С. 130 - 141.

13. Арутюнян А.А. Конституционализм: проблемы постсоветской реальности. - М.:Норма, 2013. -160 с.

14. Конституция в XXI веке: сравнительно-правовое исследование / отв. ред. В.Е. Чиркин. - М.: Норма, 2011. - 656 с.

15. Кравец И.А. Теоретико-методологические вопросы формирования конституционного правосознания // Философия образования XXI века. - Новосибирск, 2002. - №3. - C. 185 - 190.

16. Ромашев Р.А. Современный конституционализм: вопросы истории и теории. - СПб., 1998.

\section{References}

1. BochkarevS.V. Teoretiko-pravovoeopredeleniefunkcional'nogokonstit ucionalizmavotechestvennojyurisprudencii // Pravovayainiciativa. - 2014 - №2 [Elektronnyjresurs]. - URL: http://xn--b1aiui.xn--p1ai/ru/2014/2/7 (dataobrashcheniya: 22.12.2020).

2. Kabyshev V.T. Rossijskij konstitucionalizm: tendencii i perspektivy razvitiya 
// Rossijskaya yuridicheskaya doktrina v XXI veke: problemy i puti ih resheniya: Nauchno-prakticheskaya konferenciya (3-4 oktyabrya 2001g.) / Pod red. A.l. Demidova. - Saratov: SGAP, 2001

3. Stepanov I.M. Grani Rossijskogo konstitucionalizma (XX vek) // Konstitucionnyj stroj Rossii. Vyp.I.-M.,1992.

4. Stepanov I.M. Uroki i paradoksy rossijskogo konstitucionalizma. Ocherkesse.-M.,1996.

5. Avak'yan S.A. Konstituciya Rossii: priroda, evolyuciya, sovremennost'. 2-e izd.-M.,2000.

6. Avak'yan S.A. Konstituciya Rossii: priroda, evolyuciya, sovremennost'. 2-e izd.-M.,2000.

7. Romashov R.A. Konstitucionnoe gosudarstvo (istoriya, sovremennost', perspektivy razvitiya).-Krasnoyarsk: Krasnoyar. Gos. Un-t, 1997.

8. Baev V.G. Konstitucionalizm kak ponyatie i nauchnaya problema // Leningradskij yuridicheskij zhurnal.-2008.-№3(13).-S. 44-62.

9. Starshun B.A. Konstitucionalizm: ideal, real'nost' i vozmozhnye perspektivy // Sravnitel'noe konstitucionnoe obozrenie.-2011.-№5.-S. 43-47.

10. Grafskij V.G. Konstitucionalizm kak predmet izucheniya // Pravo. ZHurnal Vysshej shkoly ekonomiki.-2009.-№3.-S. 3-13.

11. Kabyshev V.T. Rossijskij konstitucionalizm na rubezhe tysyacheletij // Izvestiya vuzov. Pravovedenie.-2001.- №4.

12. Kokotov A.N., Sonina L.V. Konstitucionalizm kak politiko-pravovoj rezhim // Rossijskij yuridicheskij zhurnal.-2001.-№1.-S. 130-141.

13. Arutyunyan A.A. Konstitucionalizm: problemy postsovetskoj real'nosti.M.:Norma, 2013.- $160 \mathrm{~s}$.

14. Konstituciya v XXI veke: sravnitel'no-pravovoe issledovanie / otv. red. V.E. CHirkin. - M.: Norma, 2011. - 656 s.

15. Kravec I.A. Teoretiko-metodologicheskie voprosy formirovaniya konstitucionnogo pravosoznaniya // Filosofiya obrazovaniya XXI veka. - Novosibirsk, 2002.-№3.S. $185-190$.

16. Romashev R.A. Sovremennyj konstitucionalizm: voprosy istorii i teorii.SPb., 1998.

БЕЛЕШОВ Алексей Александрович, аспирант кафедры «теория государства и права, конституционное и административное право» юридического института ФГАОУ ВО «Южно-Уральский государственный университет» (национальный исследовательский университет). 454080, г. Челябинск, ул. Комунны, 149. E-mail: alex@partnercons.ru

BELESHOV Aleksey Alexandrovich, postgraduate student of the Department of Theory of State and Law, Constitutional and Administrative Law of the Law Institute of the Federal State Autonomous Educational Institution of Higher Education "SUSU (NRU)". 454080, Chelyabinsk, st. Communes, 149. E-mail: alex@partnercons.ru 